\title{
TP53 Mutations in Salivary Gland Neoplasms
}

\author{
Luciana Fasanella MATIZONKAS-ANTONIO ${ }^{1}$ \\ Ricardo Alves de MESQUITA ${ }^{2}$ \\ Suzana C. Orsini Machado de SOUZA ${ }^{1}$ \\ Fabio Daumas NUNES ${ }^{1}$
}

\begin{abstract}
${ }^{1}$ Department of Oral Pathology, School of Dentistry, University of São Paulo (FOUSP), São Paulo, SP, Brazil.
${ }^{2}$ Department of Oral Surgery and Pathology, School of Dentistry, Federal University of Minas Gerais (UFMG),
\end{abstract} Belo Horizonte, MG, Brazil

\begin{abstract}
Many studies have demonstrated that loss of TP53 gene function has an important role in the genesis of many neoplasms, including salivary gland neoplasms. The purpose of this study was to examine the mutation profile of the TP53 gene in salivary gland neoplasms. Genomic DNA was extracted from paraffin-embedded tissues of pleomorphic adenoma, carcinoma in pleomorphic adenoma, mucoepidermoid carcinoma, adenoid cystic carcinoma and polymorphous low grade adenocarcinoma. Exons 5 to 8 of the TP53 gene were amplified by polymerase chain reaction (PCR) to perform single-stranded conformational polymorphism (SSCP) analysis. Band shifting was observed in exons 5, 6 and 8 in 9 out of 18 neoplasms. The results of this study suggest that mutations in TP53 gene are related to salivary gland neoplasms pathogenesis and that exons 5 and 8 are most frequently involved.
\end{abstract}

Key Words: salivary gland neoplasms, TP53 gene, mutation, polymerase chain reaction, single-stranded conformational polymorphism.

\section{INTRODUCTION}

Salivary gland neoplasms constitute a wide spectrum of diseases with variable morphologic and biologic behavior. Because of their rare and heterogeneous nature, these tumors often present diagnostic and therapeutic difficulties. Most tumors show dual differentiation with a composite epithelial and myoepithelial phenotype (1). However, the mechanisms of oncogenesis and tumor progression remain unclear (2).

TP53 tumor suppressor gene is often altered in human neoplasms. This gene has been mapped on the short arm of human chromosome 17 at position $17 \mathrm{p} 13$ and encodes a 393 amino-acid nuclear phosphoprotein (3). TP53 gene has a key role in cellular control mechanisms involving cell cycle regulation, apoptosis and DNA repair (4). When DNA damage occurs, p53 acts as an emergency brake on the cell cycle, directing several powerful biological responses that yield effective damage control. The inactivation of $\mathrm{p} 53$ function eliminates a major road block in tumorigenesis (5).
Mutational inactivation of TP53 gene is one of the most frequent genetic alterations known to occur in human cancer. Mutations are dispersed over several hundred base pairs in the mid-region of the TP53 gene, mainly in exons 5 to 8 (6).

Several studies have demonstrated that loss of p53 function is an important step in the pathogenesis of many human cancers, including salivary gland neoplasms. Alterations in TP53 have been widely reported in different salivary gland tumors $(2,6-13)$. Nevertheless, the role of TP53 gene mutations in these lesions remains unclear. Therefore, the purpose of this study was to investigate mutations of TP53 gene by non-radioactive PCR-SSCP (polymerase chain reaction-single-stranded conformational polymorphism) analysis in different histological types of salivary gland neoplasm.

\section{MATERIAL AND METHODS}

Eighteen salivary gland tumors diagnosed in accordance with the Word Health Organization classification (14) and immunohistochemical features

Correspondence: Prof. Dr. Fabio Daumas Nunes, Departamento de Patologia Oral, Faculdade de Odontologia, Universidade de São Paulo, Avenida Prof. Lineu Prestes, 2227, Butantã, 05508-000 São Paulo, SP, Brasil. Tel: +55-11-3091-7902. Fax: +55-11-3091-7902. e-mail: fadnunes@usp.br 
(1) were used. Tissue samples were retrieved from the files of the Department of Oral Pathology at the School of Dentistry of the University of São Paulo (FOUSP) and comprised 5 cases of pleomorphic adenoma (PA), 2 cases of carcinoma in pleomorphic adenoma (CPA), 3 of mucoepidermoid carcinoma (MEC), 3 of adenoid cystic carcinoma (ACC) and 5 cases of polymorphous low grade adenocarcinoma (PLGA). Normal minor salivary gland tissue sections were used as controls. The research proposal was submitted to review by the Committee of Bioethics in Research at FOUSP and the designed methodology was approved.

DNA Extraction. DNA was extracted from paraffin-embedded tissue sections under sterile conditions. Twenty to thirty $10-\mu \mathrm{m}$ thick sections were cut on glass slides and areas of tumors were microdissected under microscopy. Samples were placed into $1.5 \mathrm{~mL}$ test tubes where they were dewaxed in hot xylene, washed in ethanol and incubated for 3-5 days, at $55^{\circ} \mathrm{C}$, in $50 \mu \mathrm{L}$ of DNA extraction buffer $[0.5 \mathrm{mg} / \mathrm{mL}$ proteinase $\mathrm{K}$ (Life Technologies, Gaithesburg, MD, EUA); $100 \mathrm{mmol} / \mathrm{L}$ Tris $\mathrm{HCl} \mathrm{pH} 8.25 \mathrm{mmol} / \mathrm{L}$, EDTA pH 8.0 and $0.5 \%$ sodium dodecyl sulfate]. Thirty microliter of digestion buffer with $250 \mu \mathrm{g} / \mathrm{mL}$ proteinase $\mathrm{K}$ (Life Technologies) was added daily to each tube. The enzyme was inactivated by heating for $10 \mathrm{~min}$ at $95^{\circ} \mathrm{C}$. DNA was purified with phenol, phenol-chloroformisoamil ethanol (25:24:1) and chloroform-isoamil ethanol (24:1) with centrifugation at 7,000 g for $4 \mathrm{~min}$. DNA in the top layer was collected and precipitated with $25 \mu \mathrm{L}$ of $7.5 \mathrm{~mol} / \mathrm{L}$ ammonium acetate and $1 \mathrm{~mL}$ of ice-cold $100 \%$ ethanol. DNA was pelleted by centrifugation $(16,000 \mathrm{~g}$ for $20 \mathrm{~min})$, dissolved in 20 to $40 \mu \mathrm{L}$ of TE buffer ( $10 \mathrm{mmol} / \mathrm{L}$ Tris, $1 \mathrm{mmol} / \mathrm{L}$ EDTA) and quantified using a Beckman DU 640 spectrophotometer (Beckman Instruments, Fullerton, CA, USA) $(15,16)$.
Polymerase Chain Reaction (PCR).Genomic DNA was subjected to PCR for amplification of exons $5,6,7$ and 8 of the TP53 gene. Primers were designed according to the nucleotide sequence of the TP53 gene on GeneBank (Table 1). PCR reaction was performed in a volume of $25 \mu \mathrm{L}$ containing 100-200 ng of genomic DNA, $2.5 \mu \mathrm{L}$ PCR-buffer 10X (Invitrogen, Carlsbad, CA, USA), $10 \mathrm{mM}$ of each dNTP (deoxynucleotide triphosphate), $50 \mathrm{pM}$ of each primer, $2 \mathrm{mM}$ of $\mathrm{MgCl}_{2}$ and 1 unit of Taq DNA polymerase (Invitrogen). Cycling consisted of initial denaturation at $95^{\circ} \mathrm{C}(1 \mathrm{~min})$, additional 35 rounds of denaturation $\left(1 \mathrm{~min}\right.$ at $\left.94^{\circ} \mathrm{C}\right)$, annealing $(1$ min at $58^{\circ} \mathrm{C}$ to exons 5 and 8 and $1 \mathrm{~min}$ at $60^{\circ} \mathrm{C}$ to exons 6 and 7$)$, extension $\left(1 \mathrm{~min}\right.$ at $\left.72^{\circ} \mathrm{C}\right)$ and final extension at $72^{\circ} \mathrm{C}$ (7 $\left.\mathrm{min}\right)(16)$. All PCR procedures were carried out in an automated Thermal Cycler (PTC-100; MJ Research, Inc., Watertown, MA, USA) and under sterile conditions. The resulting amplified fragments were examined on a $1 \%$ ethidium bromide-stained agarose gel.

Single-Stranded Conformational Polymorphism (SSCP). Single-stranded DNA for SSCP analysis was produced by combining equal volumes of PCR product and formamide loading buffer $(98 \%$ formamide, $10 \mathrm{mM}$ EDTA, $0.05 \%$ bromophenol blue, $0.05 \%$ xylene cyanol) and heating at $95^{\circ} \mathrm{C}$ for $10 \mathrm{~min}$. Electrophoresis was run on an $8 \%$ polyacrylamide gel with $5 \%$ glycerol at $4{ }^{\circ} \mathrm{C}$ for approximately $8 \mathrm{~h}$ and silver-stained (17). Each gel was scanned and the digitized images were transferred to Adobe Photoshop 5.01 software (Adobe Systems Inc., San Jose, CA, USA) for image editing.

\section{RESULTS}

Of 18 salivary gland tumors examined, 9 cases (2 PA, 2 CPA, 1 PLGA, 1 MEC and 3 ACC) presented

Table 1. Sequences of forward (F) and reverse (R) primers of exons 5, 6, 7 and 8 of TP53 gene and product size.

\begin{tabular}{|c|c|c|c|}
\hline Exon & $\mathrm{F}\left(3^{\prime} \rightarrow 5^{\prime}\right)$ & $\mathrm{R}\left(5^{\prime} \rightarrow 3^{\prime}\right)$ & $\mathrm{bp}$ \\
\hline 5 & TACTCCCCTGCCCTCAACAA & ACCATCGCTATCTGAGCAGC & $186 b p$ \\
\hline 6 & TGATTGCTCTTAGGTCTGGC & AGTTGCAAACCAGACCTCAG & $141 b p$ \\
\hline 7 & TCCTAGGTTGGCTCTGACT & TGACCTGGAGTCTTCCAGTG & $130 \mathrm{bp}$ \\
\hline 8 & TGGTAATCTACTGGGACGGAAC & TTGCTTACCTCGCTTAGTGCTC & $145 b p$ \\
\hline
\end{tabular}

bp: base pairs. 
alterations in the pattern of migration, compared to normal minor salivary gland, which suggests the presence of mutation in the TP53 gene (Table 2).

Five cases had alterations in exon 5 (PA5, CPA1, PLGA5, MEC3 and ACC2) (Fig. 1; Table 2) and six cases showed a different pattern of migration in exon 8 (PA1, CPA2, MEC3, ACC1, ACC2 and ACC3) (Fig. 2; Table 2). Exon 6 had only two cases (CPA2 and ACC3) with alterations that were also seen in exon 8 (Table 2). Like CPA2 and ACC3, MEC 3 and ACC2 were also altered in two exons (5 and 8 ). These cases containing alterations in two exons probably represent double mutations (Table 2). Exon 7 did not present any abnormal migration patterns suggestive of mutation.

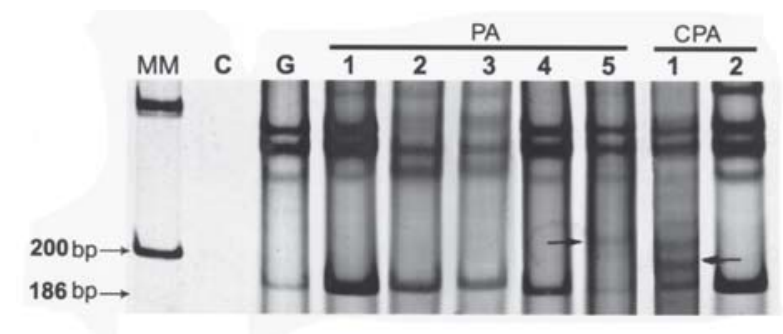

Figure 1. SSCP analysis of TP53 mutations in exon 5. Lane G shows the migration pattern of TP53 gene amplified from normal minor salivary gland tissue with $186 \mathrm{bp}$. Lanes PA5 and CPA1 show alterations in the pattern of migration suggestive of TP53 mutation. MM: molecular marker; C: PCR control without DNA; G: salivary gland; PA: pleomorphic adenoma; CPA: carcinoma in pleomorphic adenoma; SSCP: Single-stranded conformational polymorphism; bp: base pair.

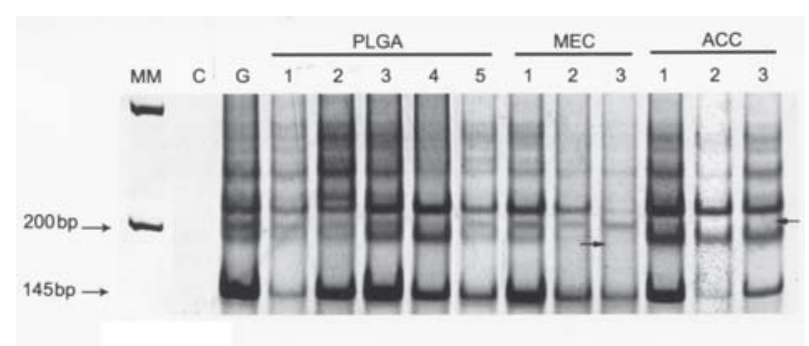

Figure 2. SSCP analysis of TP53 mutations in exon 8. Lane G shows the migration pattern of TP53 gene amplified from normal minor salivary gland tissue with 145bp. Lanes MEC3, ACC1, ACC2 and ACC3 show abnormal eletrophoretic mobilty pattern indicating the presence of TP53 mutation. MM: molecular marker; C: PCR control without DNA; G: salivary gland; PLGA: polymorphous low grade adenocarcinoma; MEC: mucoepidermoid carcinoma. ACC: adenoid cystic carcinoma; SSCP: Single-stranded conformational polymorphism; bp: base pair.
Table 2. TP53 mutations detected by SSCP analysis.

\begin{tabular}{lcccc}
\hline Case & Exon 5 & Exon 6 & Exon 7 & Exon 8 \\
\hline PA1 & - & - & - & + \\
PA2 & - & - & - & - \\
PA3 & - & - & - & - \\
PA4 & - & - & - & - \\
PA5 & + & - & - & - \\
CPA1 & + & - & - & - \\
CPA2 & - & + & - & + \\
PLGA1 & - & - & - & - \\
PLGA2 & - & - & - & - \\
PLGA3 & - & - & - & - \\
PLGA4 & - & - & - & - \\
PLGA5 & + & - & - & - \\
MEC1 (low grade) & - & - & - & - \\
MEC2 (low grade) & - & - & - & - \\
MEC3 (low grade) & + & - & - & + \\
ACC1 (cribiform) & - & - & - & + \\
ACC2 (solid) & + & - & - & + \\
ACC3 (cribiform) & - & + & - & + \\
\hline
\end{tabular}

$+:$ abnormal electrophoretic mobility pattern suggesting possible TP53 mutation; -: normal electrophoretic mobility pattern indicating no TP53 mutation. PA: Pleomorphic Adenoma; CPA: Carcinoma in Pleomorphic Adenoma; PLGA: Polymorphous Low Grade Adenocarcinoma; MEC: Mucoepidermoid Carcinoma; ACC: Adenoid Cystic Carcinoma. SSCP: single-stranded conformational polymorphism.

\section{DISCUSSION}

Over the last few years, many studies have been developed to yield more information about the relation between TP53 gene alterations and the process of oncogenesis in several lesions, including salivary glands tumors $(7-10,12,13)$.

SSCP is an indirect method for detecting TP53 mutations, deletions and insertions, while TP53 alterations without mutations are not detected. Nonradioactive SSCP can be performed effectively in routine diagnosis, and it is particularly suitable for screening a large number of patients (10). Using SSCP analysis, we found 13 abnormal band mobility patterns suggestive of TP53 gene mutation in some salivary gland tumors, mostly in exons 5 and 8 . Exon 7 did not show mutations, while exon 6 was the least affected. TP53 gene mutations in exons 5, 6 and 8 have been previously reported in salivary gland tumors $(7,10,12)$. The results of this study, together with data in literature, led us to suggest that TP53 mutations in exons 5 and 8 are most likely 
related to salivary gland neoplasms. Mutations were observed in 1 of 5 cases of PLGA, 2 of 5 cases of PA, 1 of 3 of MEC, both cases of CPA and in all 3 cases of ACC. These findings suggest that alterations in the TP53 gene may be more directly involved in the pathogenesis of aggressive malignant salivary gland tumors (CPA and ACC), and an occasional event in benign salivary gland tumors (PA).

Some authors have investigated TP53 gene status in MEC and variable results have been found. Karja et al. (9) did not observe any TP53 mutations in these lesions. On the other hand, and in agreement with our results, Nordkvist et al. (12) and Ohki et al. (2) have detected TP53 gene alterations in some lesions. Although a small number of MEC cases were analyzed in these studies, TP53 gene alterations were identified, suggesting a possible involvement of this gene in MEC pathogenesis. However, greater number of cases should be investigated for better understanding the role of TP53 gene alterations in MEC pathogenesis.

Only one of the PGLA cases examined showed a different pattern of migration suggestive of mutation. Araújo et al. (13) did not detect TP53 alterations in PLGA, but Mdm2 protein expression was observed. This can inhibit p53-mediated transactivation, possibly indicating an alternative mechanism of salivary gland tumorigenesis. Perhaps the TP53 gene may not be involved in PLGA pathogenesis and this fact could contribute for its better clinical behavior, in comparison to the other malignant salivary gland tumors. Otherwise, TP53 alterations observed in this study could be a consequence of tumor progression. Considering that PLGA is a malignant tumor with indolent clinical behavior, and that 6 to $9 \%$ of these lesions may recur or develop late metastasis, follow-up studies can elucidate if the presence of TP53 alterations would explain this change in behavior (18).

Some authors have investigated TP53 gene alterations in PA and CPA because this gene may participate in malignant transformation of PA $(7,10)$. Carcinomas may develop in the epithelial component of about $2 \%$ to $8 \%$ of PA (18). The findings of this study showed different pattern of migration suggestive of mutation in 2 of 5 cases of PA and in both cases of CPA. Previous investigations have already shown alterations of TP53 in these lesions, with markedly variable outcomes. Even though, alterations in CPA were more prevalent $(7,10,12)$. Li et al. (10) speculated that numeric abnormalities of chromosome 17 would be an early event in salivary gland neoplasm development. These abnormalities would abolish p53 function in cellular control, involving cell cycle regulation, apoptosis and DNA repair.

Our results showed a higher prevalence of mutations in CPA than in PA cases, which is consistent with the literature, and suggests that p53 could have a significant role in CPA oncogenesis. Perhaps, mutations found in PA could be a consequence of tumor progression and would imply a higher chance for malignant transformation. On the other hand, different mechanisms could be involved in PA pathogenesis, including p53 inactivation independent of mutation, as observed by other authors (13).

The role of TP53 gene in ACC pathogenesis is uncertain. Studies have correlated TP53 alterations to the recurrence of ACC (6). ACC have an aggressive biological behavior with frequent local recurrences, and metastases may become apparent many years after excision of the primary lesion $(14,19)$. This study evaluated three cases of ACC, and all three showed a different pattern of gel migration for exon 8 , which was suggestive of mutation. Yamamoto et al. $(8,11)$ reported that higher grade subtype foci of ACC presented with a higher incidence of TP53 mutations than lower grade subtype foci, mostly in solid-type foci. The authors $(8,11)$ supported that this fact could provide a genetic explanation for why proliferative activity differs between histological types, and why ACC prognosis is worse when the tumor has a predominantly solid pattern. Although it is not possible to correlate the presence of mutations with aggressive features like histological solid pattern, it seems clear that TP53 gene was altered in ACC.

The literature is scarce on papers addressing TP53 gene alterations in salivary gland neoplasms and the reports available do not describe great number of subtypes. It is therefore difficult to establish TP53 involvement in each lesion. In this study, the presence of TP53 gene mutations was demonstrated in some lesions. However, it was not possible to determine whether it was an early event or not. Different mechanisms are also involved in salivary gland tumors pathogenesis, such as loss of p14ARF gene expression and overexpression of MDM2 $(13,20)$.

In conclusion, TP53 gene alterations suggestive of mutations were frequently observed in salivary gland 
neoplasms, mostly in those with a more aggressive behavior (CPA and ACC). Exons 5 and 8 were the most frequently involved. Mutations in other exons of TP53 gene are possible and may be relevant to understand the pathogenesis and clinical behavior of tumors.

\section{RESUMO}

Vários estudos mostram que a perda da função do gene TP53 desempenha um importante papel na gênese de diversas neoplasias, incluindo as neoplasias de glândula salivar. Assim, o objetivo deste estudo foi avaliar a presença de mutações no gene TP53 em neoplasias de glândula salivar. Para isso, DNA genômico foi extraído de casos de adenoma pleomórfico (AP), carcinoma em adenoma pleomórfico (CAP), carcinoma mucoepidermóide (CME), carcinoma adenóide cístico (CAC) e adenocarcinoma polimorfo de baixo grau de malignidade (APBG) emblocados em parafina. Foi realizada amplificação pela técnica da PCR dos exons 5 a 8 e em seguida a SSCP (análise de conformação de fita simples). Foi observada alteração na mobilidade das bandas em 9 das 18 neoplasias estudadas, principalmente nos exons 5 e 8 . Esses achados sugerem que mutações no gene TP53 estão relacionadas à patogênese das neoplasias de glândula salivar e que os exons 5 e 8 estão mais freqüentemente envolvidos.

\section{ACKNOWLEDGEMENTS}

The authors acknowledge FAPESP for financial support (Process N. 97/13228-5; 01/13644-6). The authors also wish to thank Dr. Vera Cavalcanti de Araújo for critical reading and suggestions.

\section{REFERENCES}

1. Araújo VC, de Sousa SO, Carvalho YR, de Araújo NS. Application of immunohistochemistry to the diagnosis of salivary gland tumors. Appl Immunohistochem Mol Morphol 2000;8:195-202.

2. Ohki K, Kumamoto H, Ichinohasama R, Suzuki M, Yamaguchi T, Echigo S, Motegi K, Ooya K. Genetic analysis of DNA microsatellite loci in salivary gland tumours: comparison with immunohistochemical detection of Hmsh2 and P53 proteins. Int J Oral Maxillofac Surg 2001;30:538-544.

3. Argawal ML, Taylor WR, Chernov MV, Chernova OB, Stark GR. The P53 network. J Biol Chem 1998;273:1-4.

4. Moll UM, Schramm LM. P53 - an acrobat in tumorigenesis. Crit Rev Oral Biol 1998;9:23-37.

5. Levine AJ, Momand J, Finlay CA. The P53 tumour suppressor gene. Nature 1991;351:453-455.

6 Papadaki H, Finkelstein SD, Kounelis S, Bakker A, Swalsky PA, Kapadia SB. The role of P53 mutation and protein expression in primary and recurrent adenoid cystic carcinoma. Hum Pathol 1996;27:567-572.

7. Yamamoto Y, Kishimoto Y, Virmani AK, Smith A, Vuitch F, Albores-Saavedra J, Gazdar AF. Mutations associated with carcinomas arising from pleomorphic adenomas of the salivary glands. Hum Pathol 1996;27:782-786.
8. Yamamoto Y, Virmani AK, Wistuba II, McIntire D, Vuitch F, Albores-Saavedra J, Gazdar AF. Loss of heterozygosity and microsatellite alterations in P53 and RB genes in adenoid cystic carcinoma of the salivary glands. Hum Pathol 1996; 27:1204-1210.

9. Karja VJ, Syrjanen KJ, Kurvinen AK, Syrjanen SM. Expression and mutation of P53 in salivary gland tumours. J Oral Pathol Med 1997;26:217-223.

10. Li X, Tsuji T, Wen S, Mimura Y, Sasaki K, Shinozaki F. Detection of numeric abnormalities of chromosome 17 and P53 deletions by fluorescence in situ hybridization in pleomorphic adenomas and carcinomas in pleomorphic adenomas. Cancer 1997;79:2314-2319.

11. Yamamoto Y, Wistuba II, Kishimoto Y, Virmani AK, Vuitch F, Albores-Saavedra J, Gazdar AF. DNA analysis at P53 locus in adenoid cystic carcinoma: comparison of molecular study and P53 immunostaining. Pathol Int 1998;48:273-280.

12. Nordkvist A, Roijer E, Bang G, Gustafsson H, Behrendt M, Ryd W, Thoresen S, Donath K, Stenman G. Expression and mutation patterns of P53 in benign and malignant salivary gland tumors. Int J Oncol 2000;16:477-483.

13. Araújo VC, Martins MT, Leite KRM, Gomez RS, Araújo NS. Immunohistochemical Mdm2 expression in minor salivary gland tumours and its relashionship to P53 gene status. Oral Oncol 2000;36:67-69.

14. Seifert G, Sobin LH. The World Health Organization's histological classification of salivary glands tumors. A commentary on second edition. Cancer 1992;70:379-385.

15. Isola J, DeVries S, Chu L, Ghazvini S, Waldman F. Analysis of changes in DNA sequence copy number by comparative genomic hybridization in archival paraffin-embedded tumor samples. Am J Pathol 1994;145:1301-138.

16. Saiki RK, Gelfand DH, Stoffel S, Scharf SJ, Higuchi R, Horn GT, Mullis KB, Erlich HA. Primer-directed enzimatic amplification of DNA with a thermostable DNA polymerase. Science 1988;239:487-491.

17. Bassam BJ, Caetano-Anolles G, Gressho FF. Fast and sensitive silver staining of DNA in polyacrilamide gels. Anal Biochem 1991;196:80-83.

18. Lewis JE, Olsen KD, Sebo TJ. Carcinoma ex pleomorphic adenoma: pathologic analysis of 73 Cases. Hum Pathol 2001;32:596-600.

19. Hamper K, Lazar F, Dietel M, Caselitz J, Berger J, Arps H, Falkmer U, Auer G, Seifert G. Prognostic factors for adenoid cystic carcinoma of the head and neck: a retrospective evaluation of 96 cases. J Oral Pathol Med 1990;19:101-107.

20. Mantesso A, Loducca SV, Bendit I, Garicochea B, Nunes FD, de Araujo VC. Mdm2 mRNA expression in salivary gland tumour cell lines. J Oral Pathol Med 2004;33:96-101.

Accepted September 21, 2004 